\title{
Effect of liming and organic and inorganic fertilization on soil carbon sequestered in macro-and microaggregates in a 17-year old Pinus radiata silvopastoral system
}

\author{
M.R. Mosquera-Losada*, A. Rigueiro-Rodríguez, N. Ferreiro-Domínguez \\ Departamento de Producción Vegetal, Escuela Politécnica Superior de Lugo, Universidad de Santiago de Compostela, Campus Universitario s/n, 27002 Lugo, \\ Spain
}

\section{A R T I C L E I N F O}

\section{Article history:}

Received 17 April 2014

Received in revised form

14 August 2014

Accepted 13 October 2014

Available online

\section{Keywords:}

Soil organic carbon

Agroforestry systems

Clay

Silt

Sand

\begin{abstract}
A B S T R A C T
Agroforestry systems have been recognized as a potential greenhouse gas mitigation strategy under the Kyoto Protocol because of their ability to absorb carbon dioxide from the atmosphere and store carbon mainly in the soil. Soil particle size and land management practices are known to have a considerable influence on carbon storage in soils. This study evaluated changes in soil chemical and physical properties, and quantified and compared the amount of $\mathrm{C}$ stored in the bulk soil and in three different soil fractions $(250-2000,53-250$ and $<53 \mu \mathrm{m})$ at each of four soil depths $(0-25,25-50,50-75$ and 75 $-100 \mathrm{~cm}$ ) in a silvopastoral system located on an acidic forest soil under Pinus radiata D. Don. Areas of this system were subjected ten years ago to one of nine fertilization treatments: three different doses of sewage sludge or no fertilization, all with or without the addition of lime, and mineral fertilizer with no liming. Seventeen years after reforestation and seven years after canopy closure, strong gradients with soil depth were found regarding soil bulk density, $\mathrm{pH}$ and carbon storage. Intense soil management (high doses of sewage sludge and liming) generally reduced soil carbon storage, mainly in coarse aggregates, but this could be compensated by the increase in tree and pasture development observed in soils subject to intermediate sewage sludge doses.
\end{abstract}

(c) 2014 Published by Elsevier Ltd.

\section{Introduction}

The accumulation of carbon dioxide and other greenhouse gases in the atmosphere is directly related to global climate change (Jobbágy and Jackson, 2000). Ecological and low-cost methods used to allow atmospheric carbon dioxide transference into a long-lived $C$ pool is important because of its potential role in off-setting fossil fuel emissions. The establishment of silvopastoral systems, a type of agroforestry promoted by UE as a sustainable land management technique (EU, 2005), has been recognized as a possible greenhouse gas mitigation strategy under the Kyoto Protocol because of the potential for C storage in multiple plant species and in the soil (Nair et al., 2010; Mosquera-Losada et al., 2011).

In terrestrial ecosystems, soil organic matter (SOM) is considered the most important reservoir of C (Dixon, 1995; Zhang et al., 2008) because through photosynthesis and through

\footnotetext{
* Corresponding author. Tel.: +34 600942437; fax: +34 982823001.

E-mail address: mrosa.mosquera.losada@usc.es (M.R. Mosquera-Losada).
}

decomposition of trunks, branches, leaves and roots, the $\mathrm{C}$ is stored and incorporated in the soil via the action of different soil organisms (i.e., bacteria, fungi and invertebrates) (Fisher et al., 1994). This, together with the $C$ exudates from roots that are utilized by microbial populations, constitutes the natural pathways of incorporating biomass- $C$ into the soil. Decomposition in terrestrial ecosystems is determined by a set of factors organized in a hierarchy that regulates the activity of soil micro-organisms at decreasing scales of time and space in the order: climate - nutrient status + clay mineralogy + quality of resources - role of soil organisms (i.e. roots and invertebrates) (Lavelle and Spain, 2001). The soil organic $C$ is transformed biologically by the action of soil organisms (i.e., bacteria, fungi and invertebrates) and stabilized in the clay- and silt-sized organo-mineral complexes with different turnover rates. Carbon can be stored in the short-term in macroaggregates $(250-2000 \mu \mathrm{m})$ and in the long-term in micro$(53-250 \mu \mathrm{m})$ and smaller aggregate sizes $(<53 \mu \mathrm{m})$ (Howlett et al., 2011b; Nair, 2011). In addition, deciduous species generally tend to accumulate and store more $C$ in the soil compared to conifers such as Pinus radiata D. Don, due to the rapid integration of tree leaves 
and roots of the former into the soil (Fernández-Núñez et al., 2010). However, this difference is partially off-set by the higher accumulation of $\mathrm{C}$ in the tree in the case of pine plantations, as described by Palma et al. (2006).

Moreover, the extent of $C$ sequestration also varies with land management. In Galicia, the productivity of silvopastoral systems (understory and tree) may be limited by soil acidity (Zas and Alonso, 2002), and thus liming and fertilization using inorganic or organic fertilizers such as sewage sludge could improve both soil fertility and tree and understory vegetation productivity, thereby increasing soil C input (Mosquera-Losada et al., 2011). However, management activities may also result in better aeration, increased $\mathrm{pH}$ and enhanced soil fertility, thus promoting microbial activity and organic matter mineralization and in turn leading to lower SOM levels (Reijneveld et al., 2010). In general, the effect of liming and fertilization on soil $\mathrm{C}$ varies with the nature of the fertilizer, as well as with the climate and other site-specific factors (Nair, 2012).

We hypothesize that organic fertilizer use in afforested lands could be an adequate technique for long term soil carbon sequestration and therefore for climate change mitigation. Although the amount of $\mathrm{C}$ stored in the upper few centimetres of soil after afforestation has been described (Paul et al., 2002; Sauer et al., 2007; Fernández-Núñez et al., 2010), very few studies have evaluated $\mathrm{C}$ storage in different soil size fractions at different soil depths in temperate areas. The objectives of this study were i) to evaluate changes in soil chemical $(\mathrm{pH})$ and physical (bulk density and percentage of sand, silt and clay) properties and ii) to quantify and compare the amount of $\mathrm{C}$ stored in the bulk soil and in three different soil size fractions $(250-2000,53-250$, and $<53 \mu \mathrm{m})$ at four soil depths $(0-25,25-50,50-75$ and $75-100 \mathrm{~cm})$ in a silvopastoral system located on an acidic forest soil under P. radiata D. Don. Areas within this system were subjected ten years ago to one of nine fertilization treatments: three different doses of sewage sludge (160, 320 and $480 \mathrm{~kg}$ total $\mathrm{N} \mathrm{ha}^{-1}$ ) or no fertilization, all with or without liming, and mineral fertilizer $\left(8 \% \mathrm{~N}-24 \% \mathrm{P}_{2} \mathrm{O}_{5}-16 \% \mathrm{~K}_{2} \mathrm{O}\right)$ with no liming.

\section{Materials and methods}

\subsection{Characteristics of the study site}

The experiment was carried out on forestland in Pol (Lugo, Galicia, NW Spain, European Atlantic Biogeographic Region), at an altitude of $748 \mathrm{~m}$ above sea level. Soils were sedimentary and classified as Inceptisol (USDA, 2006) and acidic (the initial soil pH in water was 4.97 ), with a high initial concentration of SOM (12.32\%) and $\mathrm{N}(0.52 \%)$. At the beginning of the experiment, all soil heavy metal concentrations (Table 1 ) were below the maximum threshold for the use of sewage sludge fertilizer, as specified by European Union Directive 86/278/CEE (EU, 1986) and Spanish legislation

\section{Table 1}

Soil heavy metal concentrations at the beginning of the experiment, and the legal limits established by European Directive 86/278 and Spain R.D. 1310/1990. Limits depend on soil $\mathrm{pH}$ (minimum: soil $\mathrm{pH}<7$; maximum: soil $\mathrm{pH}>7$ ). A dash $(-$ ) indicates an element concentration below the detection limit of the technique used for its determination.

\begin{tabular}{lllllll}
\hline \multicolumn{7}{l}{ Heavy metal concentrations } \\
\cline { 2 - 7 } & $\mathrm{mg} \mathrm{kg}^{-1}$ & & & & \\
\cline { 2 - 7 } & $\mathrm{Zn}$ & $\mathrm{Cu}$ & $\mathrm{Cr}$ & $\mathrm{Cd}$ & $\mathrm{Ni}$ & $\mathrm{Pb}$ \\
\hline $\begin{array}{l}\text { Initial soil } \\
\begin{array}{c}\text { Spanish legal } \\
\text { limits }\end{array}\end{array}$ & 17.2 & 8.2 & 13.2 & - & - & - \\
\hline
\end{tabular}

under R.D. 1310/1990 (BOE, 1990). The soil texture was a sandy clay loam (63\% sand, $26 \%$ clay and $11 \%$ silt) (Guitián and Carballás, 1976).

\subsection{Experimental design}

The experiment focused on a five-year old $P$. radiata D. Don plantation with a density of 1667 trees ha $^{-1}$, while the experimental design took the form of randomized blocks with three replicates. In autumn 1997, soil was cleared and ploughed and the experimental plots established, consisting of a square of $5 \times 5$ trees covering an area of $96 \mathrm{~m}^{2}$. The latter were sown in autumn 1997 together with a mixture of $25 \mathrm{~kg} \mathrm{ha}^{-1}$ Lolium perenne var. Brigantia, $10 \mathrm{~kg} \mathrm{ha}^{-1}$ Dactylis glomerata var. Artabro and $4 \mathrm{~kg} \mathrm{ha}^{-1}$ Trifolium repens cv. Huia after ploughing. Following an initial fertilization of $120 \mathrm{~kg}$ $\mathrm{P}_{2} \mathrm{O}_{5} \mathrm{ha}^{-1}$ and $200 \mathrm{~kg} \mathrm{~K}_{2} \mathrm{O} \mathrm{ha}^{-1}$, the subsequently established experimental treatments were: no fertilization (NF) and three different sewage sludge doses based on $\mathrm{N}$ application (S1: $160 \mathrm{~kg}$ total $\mathrm{N} \mathrm{ha}^{-1}$; $\mathrm{S} 2$ : $320 \mathrm{~kg}$ total $\mathrm{N} \mathrm{ha}^{-1}$; S3: $480 \mathrm{~kg}$ total $\mathrm{N} \mathrm{ha}^{-1}$ ), all with or without liming, which was applied in 1997 before sowing $\left(2.5 \mathrm{t} \mathrm{CaCO}_{3} \mathrm{ha}^{-1}\right)$. A mineral fertilization treatment (MIN) was also established as a control; a combination of lime and MIN was not applied because this treatment is not typically used in the area. The MIN treatment consisted of the application of $500 \mathrm{~kg}$ of $8 \% \mathrm{~N}-24 \%$ $\mathrm{P}_{2} \mathrm{O}_{5}-16 \% \mathrm{~K}_{2} \mathrm{O} \mathrm{ha}^{-1}$, following conventional practice for fertilizing local pastures from 1998 to 2006. Sewage sludge was applied in 1998, 1999 and 2000, while in the following years (2001, 2002, $2003,2004,2005$ and 2006), in order to evaluate the residual effect of these treatments, mineral fertilizer was added to these plots.

\subsection{Sewage sludge}

The anaerobically-digested sludge selected for use in the fertilization treatments was obtained from Lugo municipal waste treatment plant. Sewage sludge doses were based on the percentage total $\mathrm{N}$ and dry matter content of sewage sludge (Table 2), following the U.S. Environment Protection Agency recommendation (EPA, 1994) stating that around $25 \%$ of total $\mathrm{N}$ applied will be mineralized during the first year when the sludge undergoes anaerobic digestion. EU Directive 86/278/CEE (EU, 1986) and Spanish regulation R.D. 1310/1990 (BOE, 1990) regarding heavy metal concentrations in the application of sewage sludge on soil were also considered. The composition of the sewage sludge applied in 1998, 1999 and 2000 is summarized in Table 2.

\section{Table 2}

Chemical properties of the sewage sludge and legal limits established by European Directive 86/278 and Spain R.D. 1310/1990. Limits depend on soil pH (minimum: soil $\mathrm{pH}<7$; maximum: soil $\mathrm{pH}>7$ ).

\begin{tabular}{lcccl}
\hline Parameters & Values & & & \\
\cline { 2 - 5 } & $\begin{array}{l}\text { Anaerobic } \\
\text { sludge (1998) }\end{array}$ & $\begin{array}{l}\text { Anaerobic } \\
\text { sludge (1999) }\end{array}$ & $\begin{array}{l}\text { Anaerobic } \\
\text { sludge (2000) }\end{array}$ & $\begin{array}{l}\text { Spanish } \\
\text { legal limits }\end{array}$ \\
\hline Dry matter, \% & 25 & 25 & 23.5 & \\
pH & 6.94 & 6.9 & 6.9 & \\
$\mathrm{~N}, \mathrm{~g} \mathrm{~kg}^{-1}$ & 32.1 & 32.1 & 42.3 & \\
$\mathrm{P}, \mathrm{g} \mathrm{kg}^{-1}$ & 9.3 & 5.2 & 16.5 & \\
$\mathrm{~K}, \mathrm{~g} \mathrm{~kg}^{-1}$ & 2.5 & 2.5 & 2.6 & \\
$\mathrm{Ca}, \mathrm{g} \mathrm{kg}^{-1}$ & 6.7 & 6.9 & 6.9 & \\
$\mathrm{Mg}, \mathrm{g} \mathrm{kg}^{-1}$ & 5.4 & 4.3 & 6.5 & \\
$\mathrm{Na}, \mathrm{g} \mathrm{kg}^{-1}$ & 0.8 & 0.2 & 1.4 & \\
$\mathrm{Fe}, \mathrm{g} \mathrm{kg}^{-1}$ & 19.5 & 16.1 & 22.9 & \\
$\mathrm{Mn}, \mathrm{mg} \mathrm{kg}^{-1}$ & 228 & 164 & 292 & $2500-4000$ \\
$\mathrm{Zn}, \mathrm{mg} \mathrm{kg}^{-1}$ & 821 & 746 & 1320 & $1000-1750$ \\
$\mathrm{Cu}, \mathrm{mg} \mathrm{kg}^{-1}$ & 244 & 154 & 241 & $1000-1500$ \\
$\mathrm{Cr}, \mathrm{mg} \mathrm{kg}^{-1}$ & 39 & 141 & 74 & $20-40$ \\
$\mathrm{Cd}, \mathrm{mg} \mathrm{kg}^{-1}$ & 5 & 1 & 1.5 & $300-400$ \\
$\mathrm{Ni}, \mathrm{mg} \mathrm{kg}^{-1}$ & 21 & 30 & 49 & $750-1200$ \\
$\mathrm{~Pb}, \mathrm{mg} \mathrm{kg}^{-1}$ & 203 & 94.7 & 184 & \\
\hline
\end{tabular}


Table 3

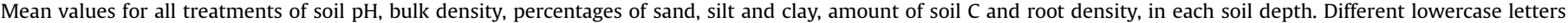

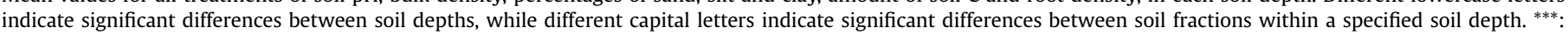
$p<0.001$, ns: not-significant, SEM: mean standard error.

\begin{tabular}{|c|c|c|c|c|c|c|c|}
\hline & \multirow[b]{2}{*}{ Parameter } & \multicolumn{4}{|c|}{ Soil depth $(\mathrm{cm})$} & \multirow[b]{2}{*}{$\begin{array}{l}\text { Depth } \\
\text { effect }\end{array}$} & \multirow[b]{2}{*}{ SEM } \\
\hline & & $0-25$ & $25-50$ & $50-75$ & $75-100$ & & \\
\hline & Water $\mathrm{pH}$ & $4.50 \mathrm{c}$ & $4.66 \mathrm{~b}$ & $4.61 \mathrm{~b}$ & $4.82 \mathrm{a}$ & $* * *$ & 0.02 \\
\hline & Bulk density $\left(\mathrm{kg} \mathrm{m}^{-3}\right)$ & $877.06 \mathrm{~b}$ & $1547.47 \mathrm{a}$ & $1611.78 \mathrm{a}$ & $1611.47 \mathrm{a}$ & $* * *$ & 34.39 \\
\hline & Sand $(\%)$ & $41.65 \mathrm{a}$ & $34.71 \mathrm{~b}$ & $26.7 \mathrm{c}$ & $24.83 \mathrm{c}$ & $* * *$ & 1.07 \\
\hline & Silt (\%) & 39.63 & 40.53 & 41.16 & 40.78 & ns & 0.56 \\
\hline & Clay (\%) & $18.72 \mathrm{c}$ & $24.76 \mathrm{~b}$ & $32.14 \mathrm{a}$ & $34.39 \mathrm{a}$ & $* * *$ & 0.84 \\
\hline & Total C $\left(\mathrm{g} \mathrm{kg}^{-1}\right)$ & $43.77 \mathrm{a}$ & $6.79 \mathrm{~b}$ & $1.74 \mathrm{c}$ & $0.89 \mathrm{c}$ & $* * *$ & 1.86 \\
\hline \multirow{8}{*}{ Soil fraction } & Total C $\left(\mathrm{Mg} \mathrm{ha}^{-1}\right)$ & $94.24 \mathrm{a}$ & $25.55 \mathrm{~b}$ & $6.98 \mathrm{c}$ & $3.6 \mathrm{c}$ & $* * *$ & 1.47 \\
\hline & $\mathrm{g} \mathrm{C} \mathrm{kg}^{-1}(250-2000 \mu \mathrm{m})$ & $21.1 \mathrm{a} \mathrm{A}$ & $1.52 \mathrm{~b} \mathrm{~B}$ & $0.24 \mathrm{~b} \mathrm{C}$ & $0.14 \mathrm{~b} \mathrm{C}$ & $* * *$ & 0.93 \\
\hline & $\mathrm{g} \mathrm{C} \mathrm{kg}^{-1}(53-250 \mu \mathrm{m})$ & 1581 a B & $2.72 \mathrm{~b} \mathrm{~A}$ & $0.55 \mathrm{c} \mathrm{B}$ & $0.3 \mathrm{c} \mathrm{B}$ & $* * *$ & 0.71 \\
\hline & $\mathrm{g} \mathrm{C} \mathrm{kg}^{-1}(<53 \mu \mathrm{m})$ & $9.03 \mathrm{a} \mathrm{C}$ & $2.72 \mathrm{~b} \mathrm{~A}$ & $0.84 \mathrm{c} \mathrm{A}$ & $0.45 \mathrm{c} \mathrm{A}$ & $* * *$ & 0.37 \\
\hline & $\mathrm{Mg} \mathrm{C} \mathrm{ha}^{-1}(250-2000 \mu \mathrm{m})$ & 44.74 a A & $5.63 \mathrm{~b} \mathrm{~B}$ & $0.99 \mathrm{c} \mathrm{C}$ & $0.59 \mathrm{c} \mathrm{C}$ & $* * *$ & 0.78 \\
\hline & $\mathrm{Mg} \mathrm{C} \mathrm{ha}^{-1}(53-250 \mu \mathrm{m})$ & 33.86 a B & $10.4 \mathrm{~b} \mathrm{~A}$ & $2.21 \mathrm{c} \mathrm{B}$ & $1.22 \mathrm{c} \mathrm{B}$ & $* * *$ & 0.27 \\
\hline & $\mathrm{Mg} \mathrm{C} \mathrm{ha}^{-1}(<53 \mu \mathrm{m})$ & 19.65 a C & $10.3 \mathrm{~b} \mathrm{~A}$ & $3.4 \mathrm{c} \mathrm{A}$ & $1.82 \mathrm{c} \mathrm{A}$ & $* * *$ & 0.32 \\
\hline & Root density $\left(\mathrm{Mg} \mathrm{ha}^{-1}\right)$ & $16.26 \mathrm{a}$ & $1.61 \mathrm{~b}$ & $0.34 \mathrm{~b}$ & $0.03 \mathrm{~b}$ & $* * *$ & 0.76 \\
\hline
\end{tabular}

\subsection{Field sampling and laboratory determination}

Soil samples were collected from the study site in January 2010 using a stainless steel cylinder with a cutting edge that was inserted using a powered hammer and removed with a platform-stabilized pulley (Moreno et al., 2005). Soil cores were collected to $1 \mathrm{~m}$, measured for depth, and divided in the field into four subsamples corresponding to sampling depth classes of $0-25,25-50,50-75$ and $75-100 \mathrm{~cm}$. The sampling depth class of $0-25 \mathrm{~cm}$ was selected

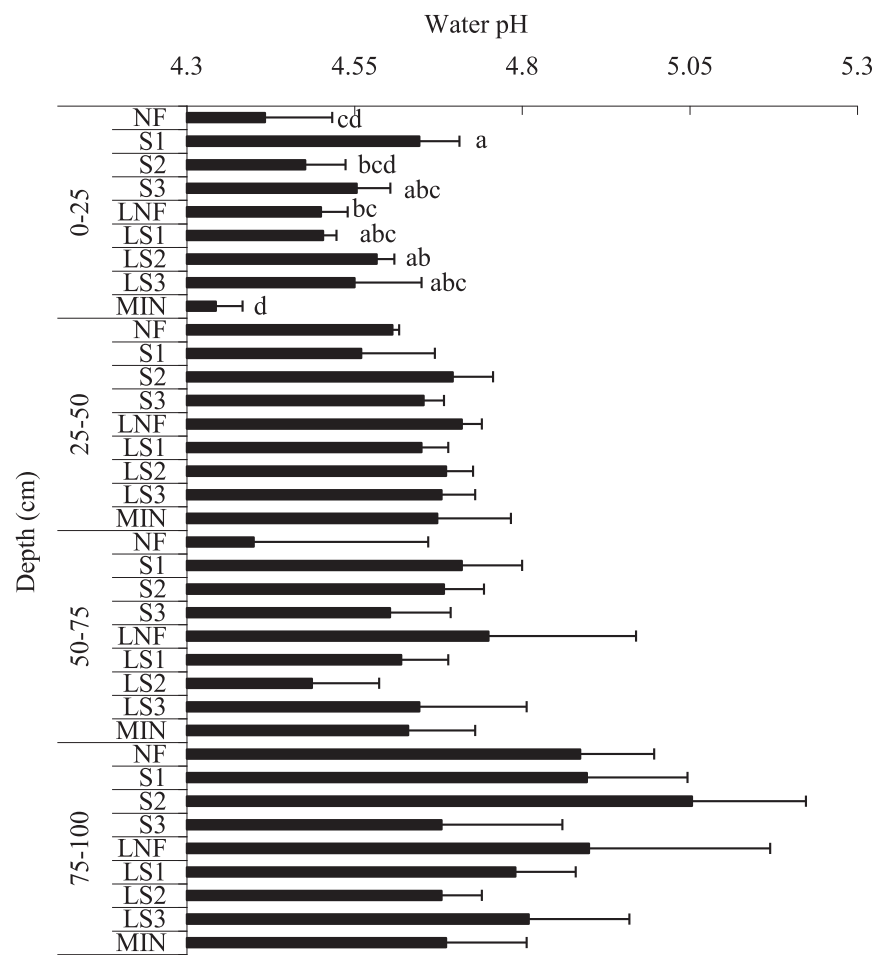

Fig. 1. Soil pH under each treatment at four soil depths $(0-25,25-50,50-75$ and 75-100 cm). NF: no fertilizer; S1: low sewage sludge dose (160 $\mathrm{kg}_{\text {total }} \mathrm{N} \mathrm{ha}^{-1}$ ); S2: medium sewage sludge dose ( $320 \mathrm{~kg}$ total $\left.\mathrm{N} \mathrm{ha}^{-1}\right)$; S3: high sewage sludge dose (480 kg total $\mathrm{N} \mathrm{ha}^{-1}$ ) and MIN: mineral fertilizer. Different letters indicate significant differences between fertilizer treatments within a specified depth and treatments are no significantly different if no letters are shown. Horizontal lines indicate mean standard error. following the recommendations of the R.D. 1310/1990 (BOE, 1990) and the other sampling depth classes were selected to have equal intervals. Soil roots in each subsample were separated by hand. Soil bulk density and density of roots were determined for each sampling depth using a cylinder of known volume.

Soil samples were air-dried and passed through a $2 \mathrm{~mm}$ sieve, with the portion of soil not passing through the sieve separated, weighed and discarded. The weight of this discarded fraction was noted down in order to convert the data subsequently derived from the $2 \mathrm{~mm}$-sieved fraction back to field conditions (RodriguezMurillo, 2001; Six et al., 2002a). Soil samples were ground for homogenization and analysed in a LECO C.N.H.S. Elemental Analyzer (LECO, St. Joseph, MI) for percentage $C$ within 2 weeks of being airdried (Kowalenko, 2001). Soil pH was determined in water $(1: 2.5)$ using a Crison $\mathrm{pH}$ meter at $20^{\circ} \mathrm{C}$ (Faithfull, 2002).

The bulk soil was physically fractionated according to Elliott (1986) and Six et al. (2002b). Initially, a $25 \mathrm{~g}$ sample of $2 \mathrm{~mm}$ sieved air-dried soil of known moisture content was placed in a $250 \mathrm{ml}$ beaker. Distilled water $(150 \mathrm{ml})$, enough to completely cover the soil, was poured into the beaker to promote slaking. The slaking process breaks up water-unstable aggregates in the soil, leaving behind water-stable aggregates for further analysis. After $5 \mathrm{~min}$, slaked soil was poured on top of a $250 \mu \mathrm{m}$ sieve (\#60 U.S. Standard Testing Sieve), with the soil solution wet-sieved manually by moving the sieve up and down by about $5 \mathrm{~cm}$ in each direction. After this action was carried out 50 times in two minutes, material not passing through the $250 \mu \mathrm{m}$ sieve was backwashed, using a distilled water-filled wash bottle, into a pre-weighed and numbered aluminium plate. The remaining soil solution was then poured over a $53 \mu \mathrm{m}$ sieve (\#270 U.S. Standard Testing Sieve) and the above-described procedure repeated. Material not passing through the $53-\mu \mathrm{m}$ sieve was backwashed into a similarly preweighed and numbered aluminium plate. Finally, the remaining soil solution passing through the $53 \mu \mathrm{m}$ sieve was poured into another pre-weighed and numbered aluminium plate. The three soil fractions (250-2000, 53-250 and $<53 \mu \mathrm{m}$ ) were then dried at $60{ }^{\circ} \mathrm{C}$ overnight, weighed, ground for homogenization and stored in individually sealed and labelled plastic bags for further $C$ analysis. Samples were analysed in a LECO C.N.H.S. Elemental Analyzer (LECO, St. Joseph, MI) for percentage $C$ within 2 weeks after airdrying of bulk soil (Kowalenko, 2001).

In order to facilitate comparison with most soil from the literature, the soil $\mathrm{C}$ concentration of bulk soil and soil fraction samples 
Bulk density $\left(\mathrm{kg} \mathrm{m}^{-3}\right)$

760

1260

1510

1760

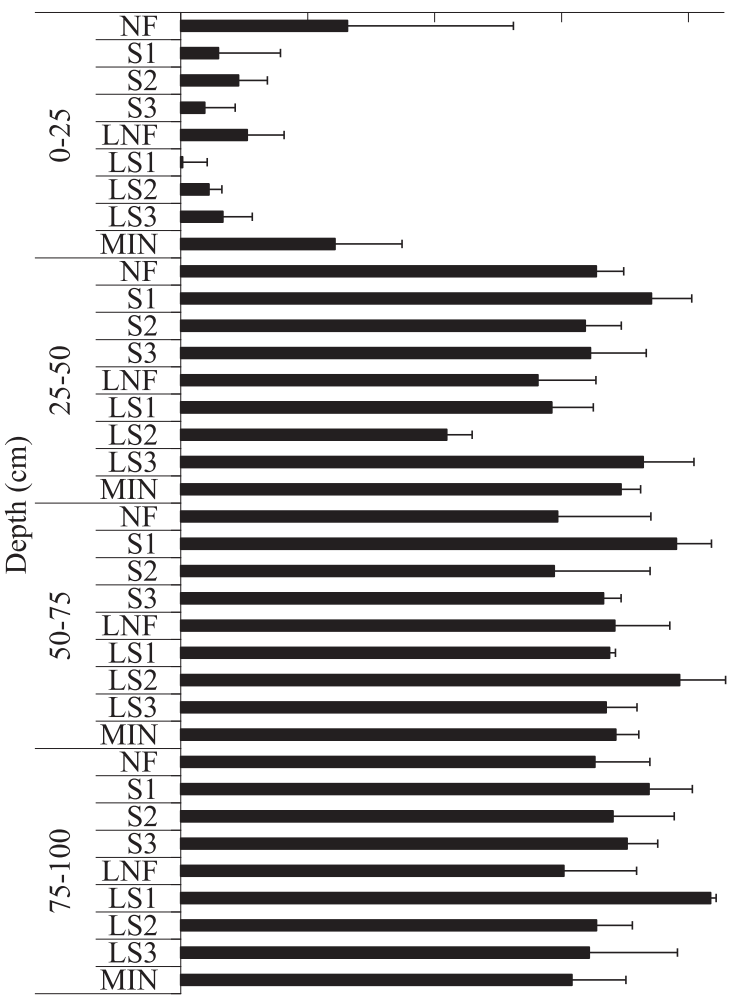

Silt (\%)

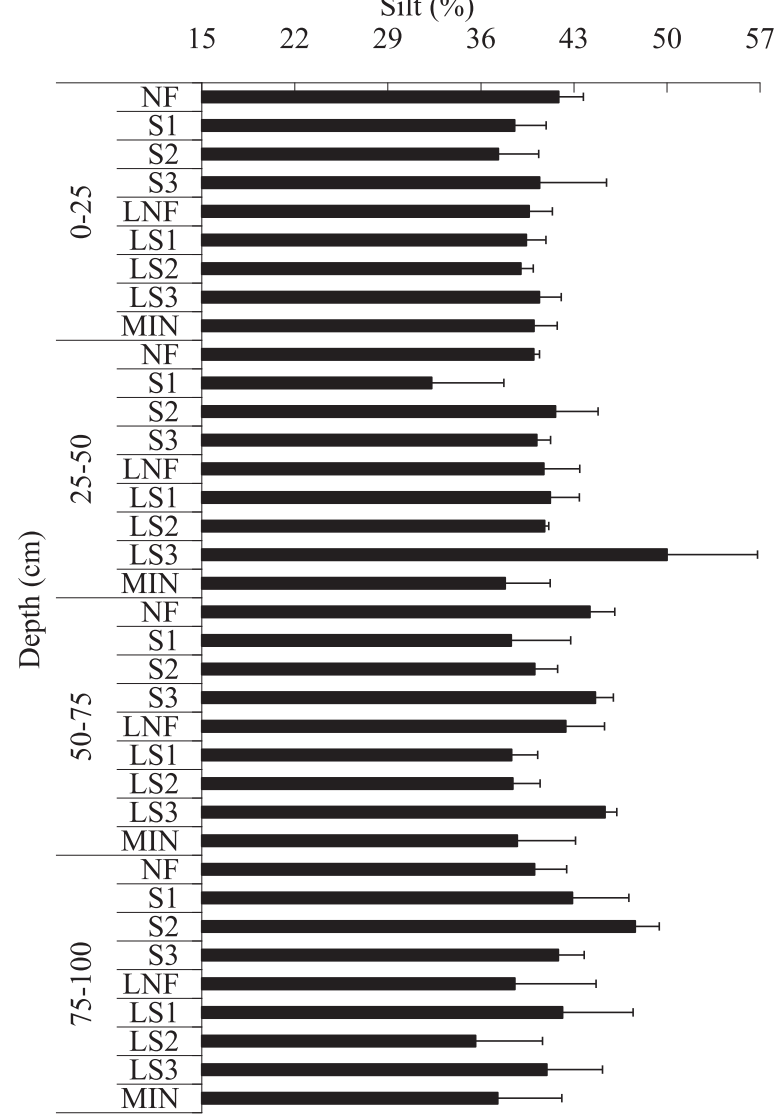

Sand $(\%)$

$\begin{array}{lllllll}15 & 22 & 29 & 36 & 43 & 50 & 57\end{array}$
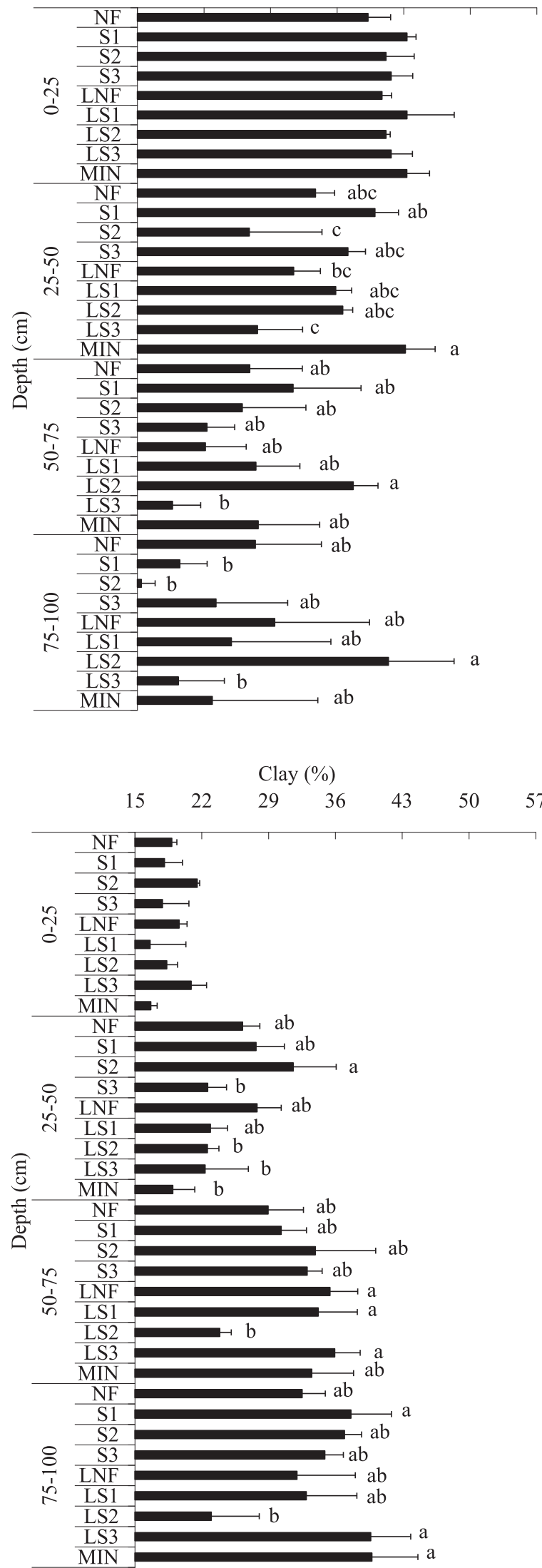

Fig. 2. Soil bulk density $\left(\mathrm{kg} \mathrm{m}^{-3}\right)$ and percentage of sand, silt and clay under each treatment at four soil depths $(0-25,25-50,50-75$ and $75-100 \mathrm{~cm})$. NF: no fertilizer; S1: low sewage sludge dose (160 $\mathrm{kg}$ total $\left.\mathrm{N} \mathrm{ha}^{-1}\right)$; S2: medium sewage sludge dose (320 kg total N ha $\left.{ }^{-1}\right)$; S3: high sewage sludge dose $\left(480 \mathrm{~kg}_{\text {total N ha }}^{-1}\right)$ and MIN: mineral fertilizer. Different letters indicate significant differences between fertilizer treatments within a specified depth and treatments are no significantly different if no letters are shown. Horizontal lines indicate mean standard error. 
was expressed in $\mathrm{g} \mathrm{C}$ per total $\mathrm{kg}$ of soil using the following formula:

$$
\begin{gathered}
\left(\frac{\mathrm{g} \mathrm{C}}{\mathrm{g}<2 \mathrm{~mm} \text { soil }}\right) \times\left(\frac{\mathrm{g}<2 \mathrm{~mm} \text { soil }}{\mathrm{g} \text { bulk soil }}\right) \times\left(\frac{10^{3} \mathrm{~g} \text { bulk soil }}{1 \mathrm{~kg} \text { bulk soil }}\right) \\
\times\left(\frac{\mathrm{g} \text { fraction soil }}{\mathrm{g}<2 \mathrm{~mm} \text { soil }}\right)^{*}=\mathrm{g} \mathrm{C} \mathrm{kg}^{-1} \text { soil }
\end{gathered}
$$

* this final term is required only to calculate $\mathrm{g}$ per total $\mathrm{kg}$ of soil in fractionated soil.

In addition, the mean bulk density of soil at each sampling depth was used to convert $\mathrm{C}$ percentages in the bulk soil and fractions to $\mathrm{Mg}$ C per hectare (to a specified depth, e.g. $25 \mathrm{~cm}$ ) via the following formula:

$$
\begin{aligned}
& \left(\frac{\mathrm{g} \mathrm{C}}{\mathrm{g}<2 \mathrm{~mm} \mathrm{soil}}\right) \times\left(\frac{\mathrm{g}<2 \mathrm{~mm} \text { soil }}{\mathrm{g} \text { bulk soil }}\right) \times\left(\frac{\mathrm{g} \text { bulk soil }}{\mathrm{cm}^{3}}\right) \\
& \times\left(\frac{25 \mathrm{~cm}}{1}\right) \times 100 \times\left(\frac{\mathrm{g} \text { fraction soil }}{\mathrm{g}<2 \mathrm{~mm} \mathrm{soil}}\right)^{*}=\mathrm{Mg} \mathrm{C} \mathrm{ha}{ }^{-1}
\end{aligned}
$$

*this final term is required only to calculate $\mathrm{Mg} \mathrm{C}$ ha ${ }^{-1}$ in fractionated soil.

\subsection{Statistical analysis}

The data obtained from soil and roots followed a normal distribution and were analysed by ANOVA (proc glm procedure) using the model $\mathrm{Y}_{\mathrm{ijkl}}=\mu+\mathrm{L}_{\mathrm{i}}+\mathrm{F}_{\mathrm{j}}+\mathrm{D}_{\mathrm{k}}+\mathrm{B}_{\mathrm{l}}+\mathrm{LF}_{\mathrm{ij}}+\mathrm{LD}_{\mathrm{ik}}+$ $\mathrm{LB}_{\mathrm{il}}+\mathrm{FD}_{\mathrm{jk}}+\mathrm{FB}_{\mathrm{jl}}+\mathrm{DB}_{\mathrm{kl}}+\mathrm{LFD}_{\mathrm{ijk}}+\mathrm{LFB}_{\mathrm{ijl}}+\mathrm{FDB}_{\mathrm{jkl}}+\varepsilon_{\mathrm{ijkl}}$, where $\mathrm{Y}_{\mathrm{ijkl}}$ is the studied variable, $\mu$ the variable mean, $L_{i}$ the lime effect, $F_{j}$ the fertilizer treatment effect, $D_{k}$ the depth effect, $B_{1}$ block 1 and their double and triple interactions, and $\varepsilon_{\mathrm{ijkl}}$ the error component. The effect of soil fraction (250-2000, 53-250 and $<53 \mu \mathrm{m})$ on soil C storage was also taken into account.

The LSD test was employed to make subsequent pair-wise comparisons $(p<0.05 ; \mathrm{a}=0.05)$ if the ANOVA was significant. The statistical software package SAS (2001) was used for all analyses.

\section{Results}

\subsection{Soil $p H$}

As shown in Table 3, soil pH increased significantly with soil depth, while a significant interaction between lime $\times$ fertilization on soil $\mathrm{pH}(p<0.05)$ was also observed (Fig. 1). At $0-25 \mathrm{~cm}$ soil depth, no differences were seen between limed and unlimed treatments when comparing the same levels and type of fertilizer. However, among the unlimed treatments, a higher soil $\mathrm{pH}$ was found in those plots fertilized with a low (S1: $160 \mathrm{~kg}$ total $\mathrm{N} \mathrm{ha}^{-1}$ ) dose of sewage sludge than in those receiving either a medium (S2: $320 \mathrm{~kg}$ total $\mathrm{N} \mathrm{ha}^{-1}$ ) dose or NF and MIN treatment. Finally, when all treatments were compared with the two controls (MIN and NF without lime), it was observed that both control treatments had the lowest soil $\mathrm{pH}$ with respect to that involving the combination of lime and a medium dose of sewage sludge. In all other soil depth classes $(25-50,50-75$ and $75-100 \mathrm{~cm})$, no clear effect of any treatment on soil $\mathrm{pH}$ was apparent.

\subsection{Soil bulk density and percentages of sand, silt and clay}

Table 3 reveals soil at $0-25 \mathrm{~cm}$ depth to be characterized by a lower bulk density than other layers. In contrast, the percentage of sand decreased significantly with soil depth, while the percentage of clay was significantly higher at $50-75 \mathrm{~cm}$ and $75-100 \mathrm{~cm}$ than in the shallower depth classes. The percentage of silt did not vary significantly with soil depth $(p>0.05)$.

No significant effect on either soil bulk density or the percentage of silt was found for any treatment at any soil depth $(p>0.05)$. However, the percentages of sand and clay were both modified by the interaction between lime $\times$ fertilization $(p<0.001)$ (Fig. 2$)$. In the case of the percentage of sand, the lime effect was not evident when the same dose of fertilizer was applied at 25-50 and $50-75 \mathrm{~cm}$ depth, but at $75-100 \mathrm{~cm}$ the percentage of sand significantly increased with liming when a medium dose of sewage sludge was applied. Within unlimed treatments, a higher percentage of sand in the soil was found at $25-50 \mathrm{~cm}$ depth in those plots fertilized with a low dose of sewage sludge compared with a medium dose of this residue. Moreover, in the $50-75 \mathrm{~cm}$ and 75-100 cm depth classes, fertilization of limed treatments with a medium dose of sewage sludge increased the percentage of sand in the soil when compared with a high (S3: $480 \mathrm{~kg}$ total $\mathrm{N} \mathrm{ha}^{-1}$ ) dose. In contrast, soils subject to either the application of lime without sewage sludge (NF), a high dose of sewage sludge with lime, or a medium dose without lime, were all characterized by an increase of the percentage of sand in the soil at $25-50 \mathrm{~cm}$ depth with respect to that undergoing the MIN treatment.

The percentage of clay at $25-50 \mathrm{~cm}$ depth was significantly increased by lime input when a medium dose of sewage sludge was applied. Among the limed treatments, fertilization with a medium dose of sewage sludge was accompanied by a significant reduction in the percentage of clay both at $50-75 \mathrm{~cm}$ soil depth in comparison to all other limed treatments, and at $75-100 \mathrm{~cm}$ depth with respect to the treatment involving a high dose of sewage sludge. In contrast, amongst unlimed treatments a medium dose of sewage sludge increased the percentage of clay at $25-50 \mathrm{~cm}$ depth with respect to that subject to either a high dose of the residue or MIN treatment. However, in limed soil at depths of $50-75 \mathrm{~cm}$ and 75-100 $\mathrm{cm}$ the reverse effect regarding MIN treatment was observed, with the percentage of clay higher than in the treatment in which lime and medium dose of sewage sludge were combined.

\subsection{Total $C$ in bulk soil and in the soil fractions (250-2000, 53-250 and $<53 \mu \mathrm{m}$ )}

Bulk soil total $\mathrm{C}$ and $\mathrm{C}$ stored in the soil fractions of 250-2000 $\mu \mathrm{m}, 53-250 \mu \mathrm{m}$ and $<53 \mu \mathrm{m}$ (when expressed as either $\mathrm{g} \mathrm{C}$ per total $\mathrm{kg}$ of soil or $\mathrm{Mg} \mathrm{C} \mathrm{ha}^{-1}$ ) were significantly higher in the upper two soil layers $(0-25$ and $25-50 \mathrm{~cm})$ than at lower depths $(p<0.001)$ (Table 3$)$.

Moreover, as also revealed in Table 3, a significant relationship was found between soil fraction and the amount of soil $C$ at all depths $(p<0.001)$. In the uppermost soil layer, levels of $C$ stored in the $250-2000 \mu \mathrm{m}$ soil fraction were greater than those in the other fractions. However, the opposite result was observed in the 25-50 cm soil depth class. At 50-75 cm and 75-100 cm depth, the largest amount of $\mathrm{C}$ was stored in the $<53 \mu \mathrm{m}$ fraction.

Bulk soil total C $\left(\mathrm{g} \mathrm{kg}^{-1}\right)$ and the $C$ stored in the $250-2000 \mu \mathrm{m}$ soil fraction $\left(\mathrm{g} \mathrm{kg}^{-1}\right)$ were significantly modified at different depths by the type of fertilizer applied $(p<0.05)$ (Fig. 3). In the other soil fractions (53-250 $\mu \mathrm{m}$ and $<53 \mu \mathrm{m})$, no significant effect of lime and type of fertilizer was observed in relation to soil $C(p>0.05)$. In the $25-50 \mathrm{~cm}$ soil depth class of limed plots, the application of low and medium doses of sewage sludge was associated with a higher amount of bulk soil total $C$ than in those soils subject to a high dose of the residue. The same result was also observed with respect to the amount of $C$ stored in the $250-2000 \mu \mathrm{m}$ soil fraction at depths of $0-25 \mathrm{~cm}$ and $25-50 \mathrm{~cm}$. However, in the $75-100 \mathrm{~cm}$ depth class the positive effect of sludge application on $C$ stored in the 
Total C $\left(\mathrm{g} \mathrm{kg}^{-1}\right)$

$\begin{array}{llllllll}0 & 10 & 20 & 30 & 40 & 50 & 60 & 70\end{array}$

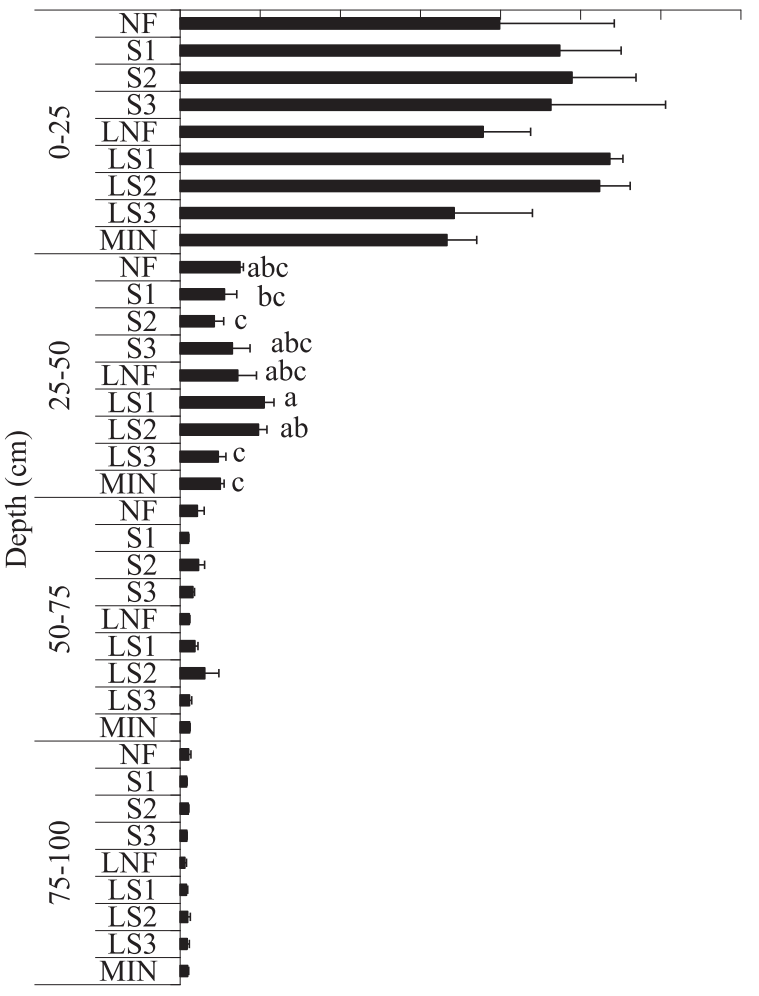

$\mathrm{g} \mathrm{C} \mathrm{kg}^{-1}(53-250 \mu \mathrm{m})$

$\begin{array}{llllllll}0 & 10 & 20 & 30 & 40 & 50 & 60 & 70\end{array}$

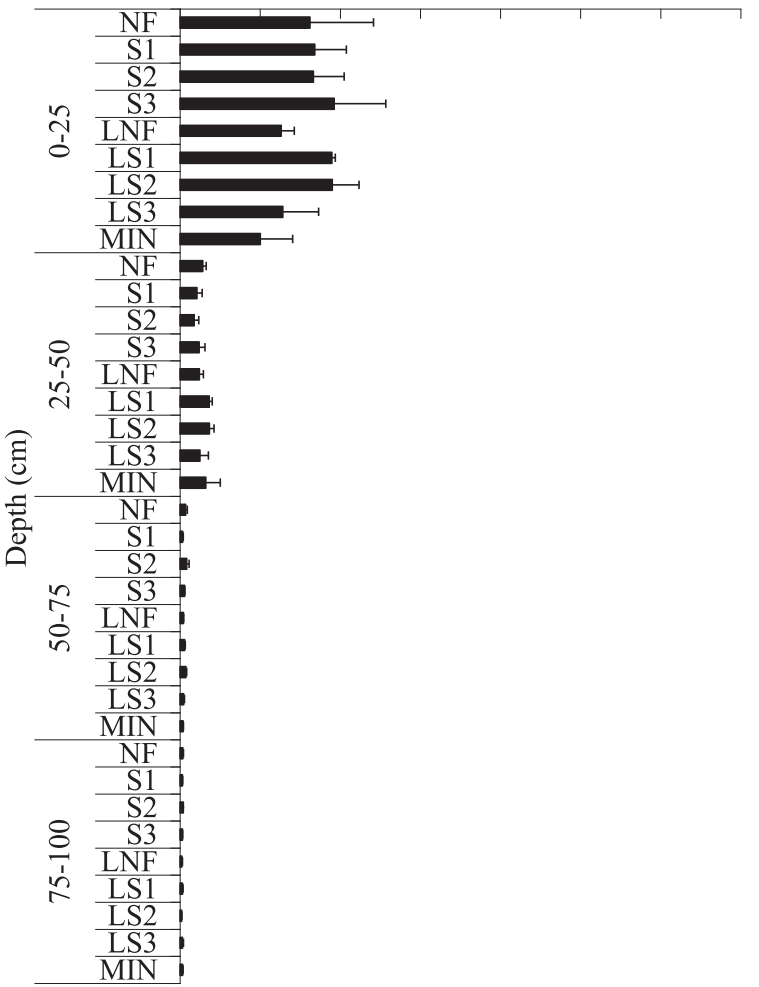

$\mathrm{g} \mathrm{C} \mathrm{kg}^{-1}(250-2000 \mu \mathrm{m})$

$\begin{array}{llllllll}0 & 10 & 20 & 30 & 40 & 50 & 60 & 70\end{array}$

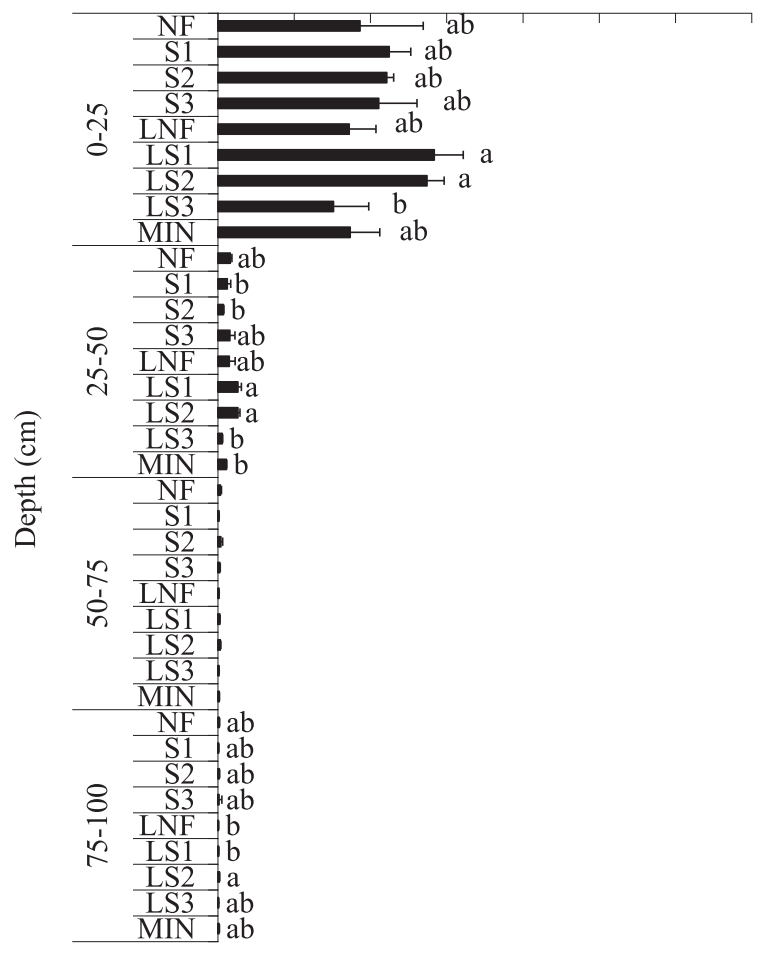

$\mathrm{C} \mathrm{kg}^{-1}(<53 \mu \mathrm{m})$

$\begin{array}{llllllll}0 & 10 & 20 & 30 & 40 & 50 & 60 & 70\end{array}$

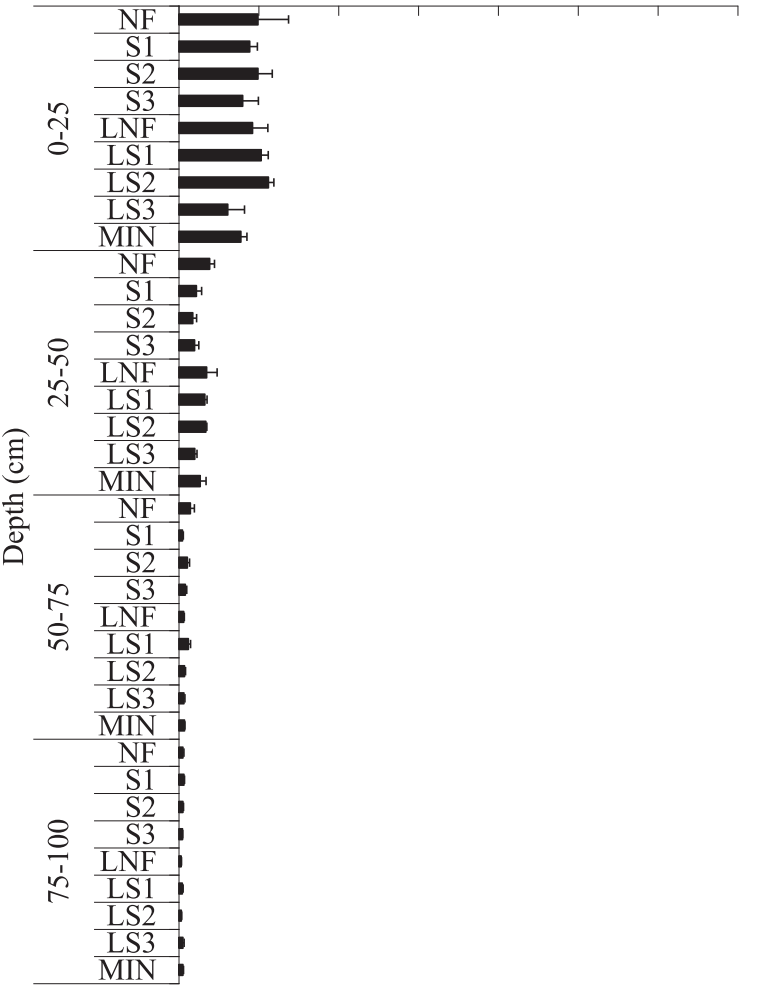

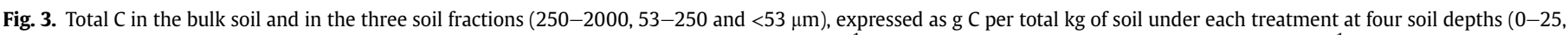

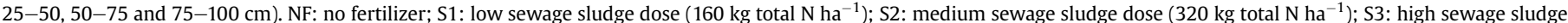

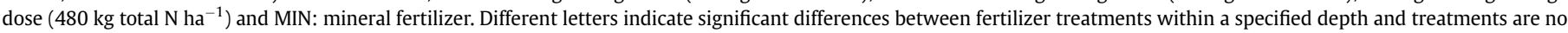
significantly different if no letters are shown. Horizontal lines indicate mean standard error. 
Total C $\left(\mathrm{Mg} \mathrm{ha}^{-1}\right)$

$\begin{array}{llllllllll}0 & 15 & 30 & 45 & 60 & 75 & 90 & 105 & 120 & 135\end{array}$
$\mathrm{Mg} \mathrm{C} \mathrm{ha-1}(250-2000 \mu \mathrm{m})$

$\begin{array}{llllllllll}0 & 15 & 30 & 45 & 60 & 75 & 90 & 105 & 120 & 135\end{array}$
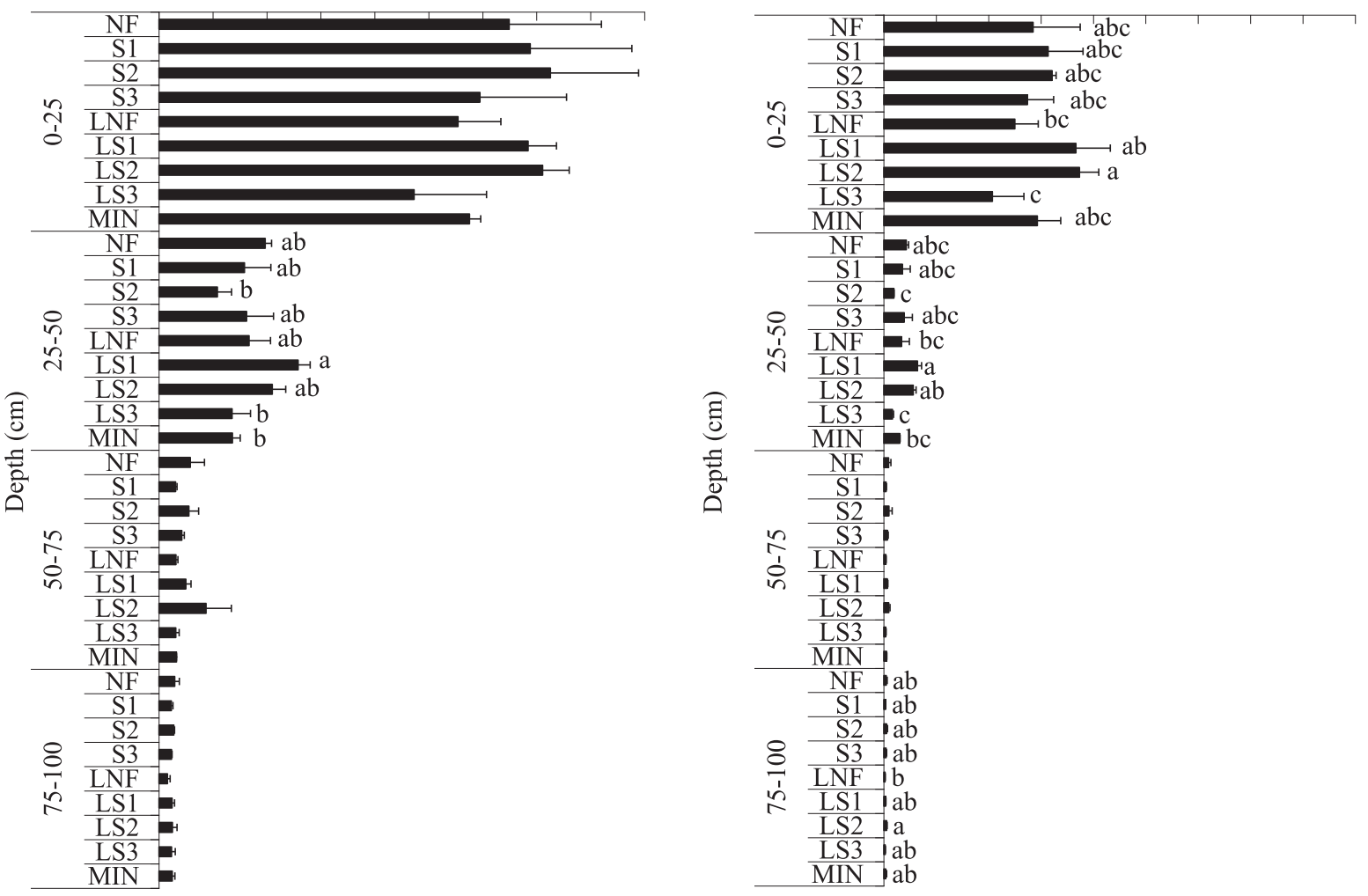

$\mathrm{Mg} \mathrm{C}$ ha $^{-1}(53-250 \mu \mathrm{m})$

$\begin{array}{llllllllll}0 & 15 & 30 & 45 & 60 & 75 & 90 & 105 & 120 & 135\end{array}$

$\mathrm{Mg} \mathrm{Cha}^{-1}(<53 \mu \mathrm{m})$

$\begin{array}{llllllllll}0 & 15 & 30 & 45 & 60 & 75 & 90 & 105 & 120 & 135\end{array}$
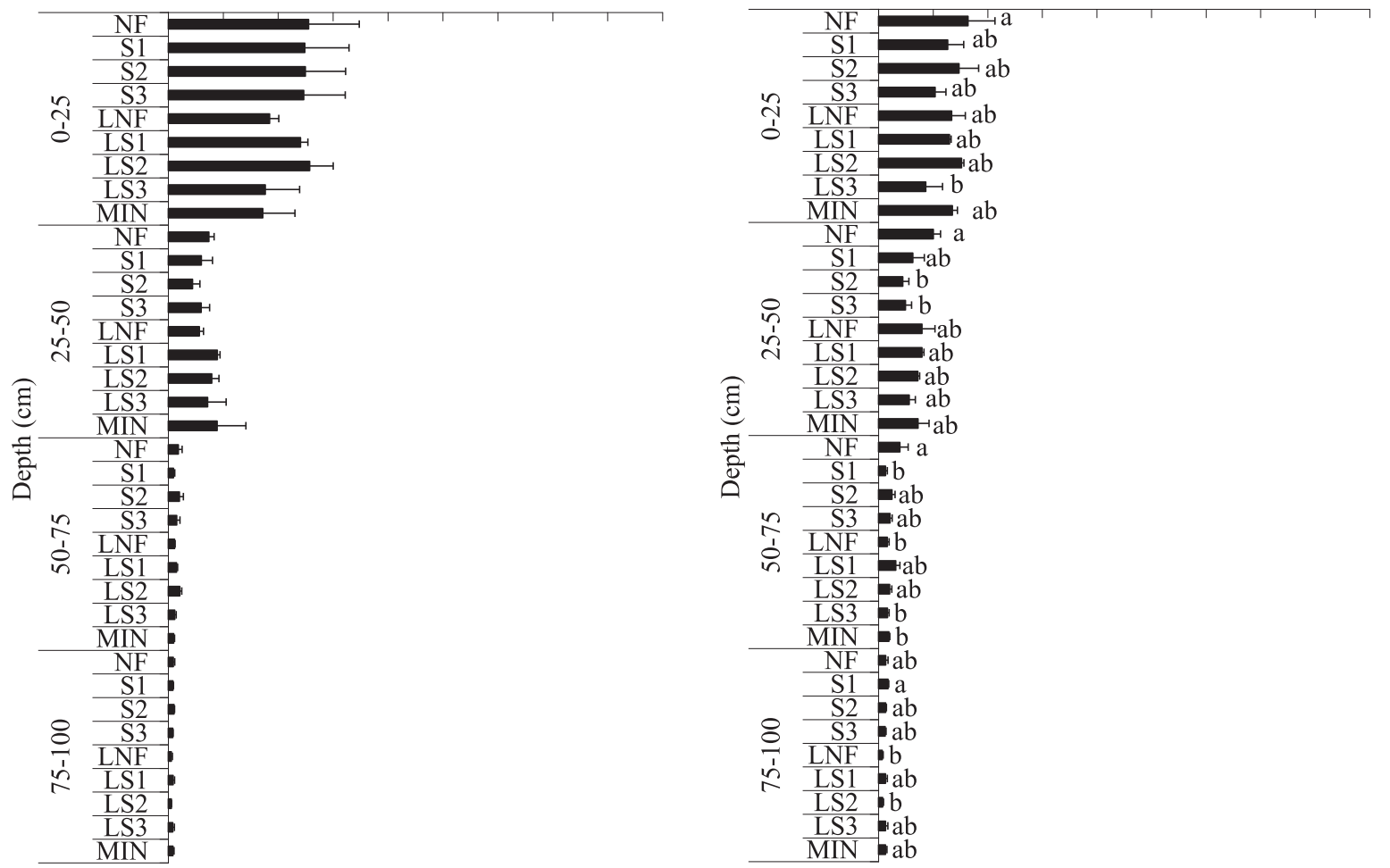

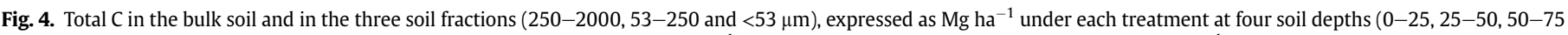

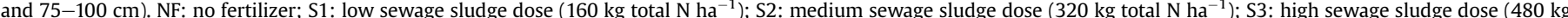

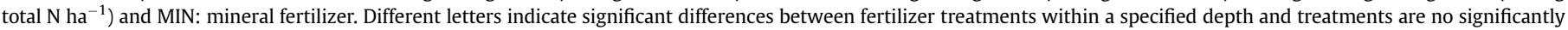
different if no letters are shown. Horizontal lines indicate mean standard error. 
250-2000 $\mu \mathrm{m}$ soil fraction was only evident when a medium dose of sewage sludge was applied compared with a low sludge dose or the NF treatment. At the same time, when all established treatments were compared with the MIN control treatment, it was found that the mineral treatment reduced bulk soil total $\mathrm{C}$ and the amount of $C$ stored in the $250-2000 \mu \mathrm{m}$ soil fraction at $25-50 \mathrm{~cm}$ depth to a greater extent than did the combination of lime and a low dose of sewage sludge.

Results regarding bulk soil total $\mathrm{C}$ and $\mathrm{C}$ stored in the different soil fractions were generally similar when expressed either as $\mathrm{Mg}$ $\mathrm{ha}^{-1}$ (Fig. 4) or as g C per total $\mathrm{kg}$ of soil, with the exception of the level of $C$ stored in the $<53 \mu \mathrm{m}$ soil fraction. In this latter fraction, amounts of $C$ were greater at $0-25 \mathrm{~cm}$ soil depth in the NF treatment plot than in those subject to either a combination of lime and a high dose of sewage sludge, or a medium or high dose of sewage sludge without lime. $\mathrm{C}$ levels were also greater in the NF plot at $50-75 \mathrm{~cm}$ depth $(p<0.05)$ compared with either a low dose of sludge without lime or a high sludge dose with lime.

Finally, in the upper metre of soil (Fig. 5), total C and that stored in the $250-2000 \mu \mathrm{m}$ and $<53 \mu \mathrm{m}$ soil fractions, when expressed as $\mathrm{Mg} \mathrm{ha}{ }^{-1}$ were significantly affected by the lime $\times$ fertilization interaction $(p<0.05)$. However, no significant relationship was observed between levels of either $C$ stored in the $53-250 \mu \mathrm{m}$ soil fraction $\left(\mathrm{Mg} \mathrm{ha}^{-1}\right)$ or of $\mathrm{C}$ expressed as $\mathrm{g} C$ per total $\mathrm{kg}$ of soil with any of the treatments applied ( $p>0.05$ ) (data not shown). Within the limed treatments, the application of a high dose of sewage sludge reduced both total $C$ and that found in the $250-2000 \mu \mathrm{m}$ soil fraction in comparison with low and medium sludge doses. Moreover, in the 250-2000 $\mu \mathrm{m}$ soil fraction, less $C$ was found in plots under the NF treatment than in those in which lime and either a low or medium dose of sewage sludge were combined. In contrast, more $\mathrm{C}$ was found stored in the $<53 \mu \mathrm{m}$ soil fraction in the
NF plot than in those treated by either a low or high dose of sewage sludge without lime, or a high dose of sludge with lime.

\subsection{Root density}

Table 3 shows that root density was significantly higher at $0-25 \mathrm{~cm}$ depth than elsewhere in the soil section. However, no significant effect of treatment (liming and fertilization with sewage sludge) on root density was observed at any soil depth $(p>0.05)$ (Fig. 6).

\section{Discussion}

\subsection{Soil depth effect on physico-chemical properties}

In silvopastoral systems, soil $\mathrm{C}$ sequestration depends on activity of soil organisms, soil chemical characteristics, such as $\mathrm{pH}$, and physical properties which may change with soil depth profile (Jobbágy and Jackson, 2000). The present experiment was established on a very acid soil, a property which can limit microbial activity and organic matter mineralization, in turn leading to high SOM levels (Reijneveld et al., 2010). Moreover, soil pH increased with depth mainly due to the fact that lime and sewage application did not take place every year, the leaching of cations through the soil profile and their extraction by trees and pasture (Whitehead, 1995; Nillsson, 2004; López-Díaz et al., 2007). This process is typical of unmanaged soils. In addition, soil cation extraction was probably more intense at $0-25 \mathrm{~cm}$ depth than elsewhere in the profile due to the high root density observed in the upper soil layers during the experiment. Another factor that could also imply a relatively greater reduction in soil $\mathrm{pH}$ at $0-25 \mathrm{~cm}$ depth is the arboreal deposition of acidifying material such as pine needles. The
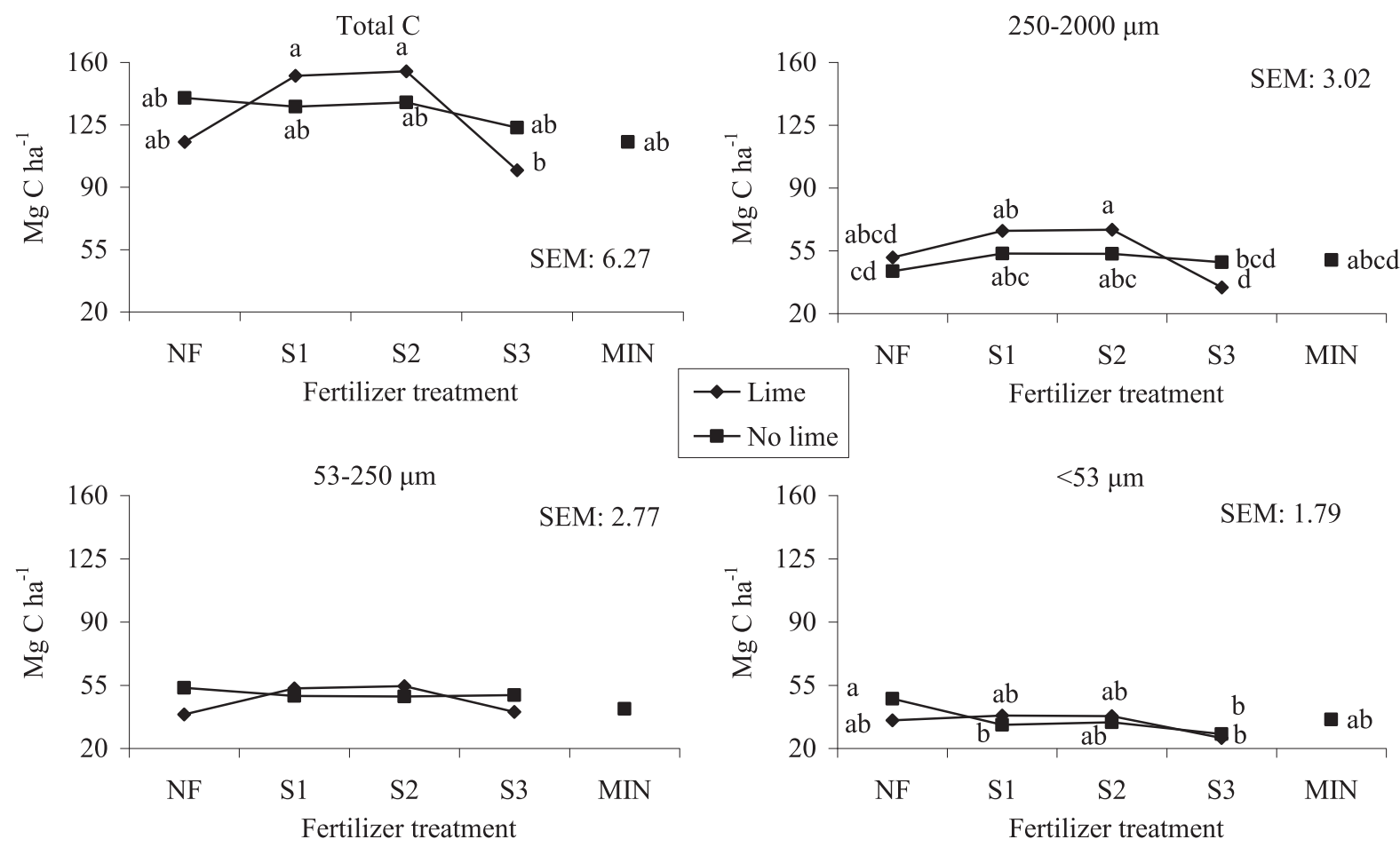

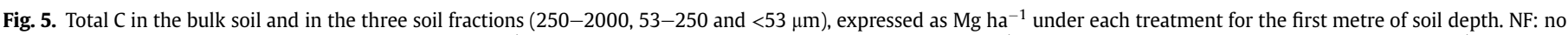

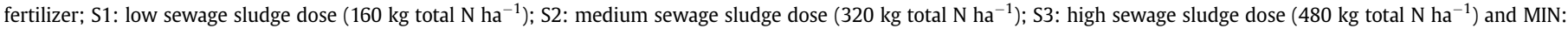

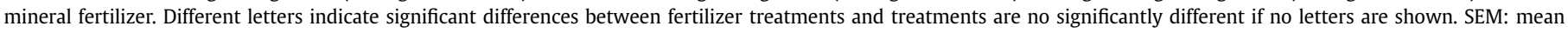
standard error. 


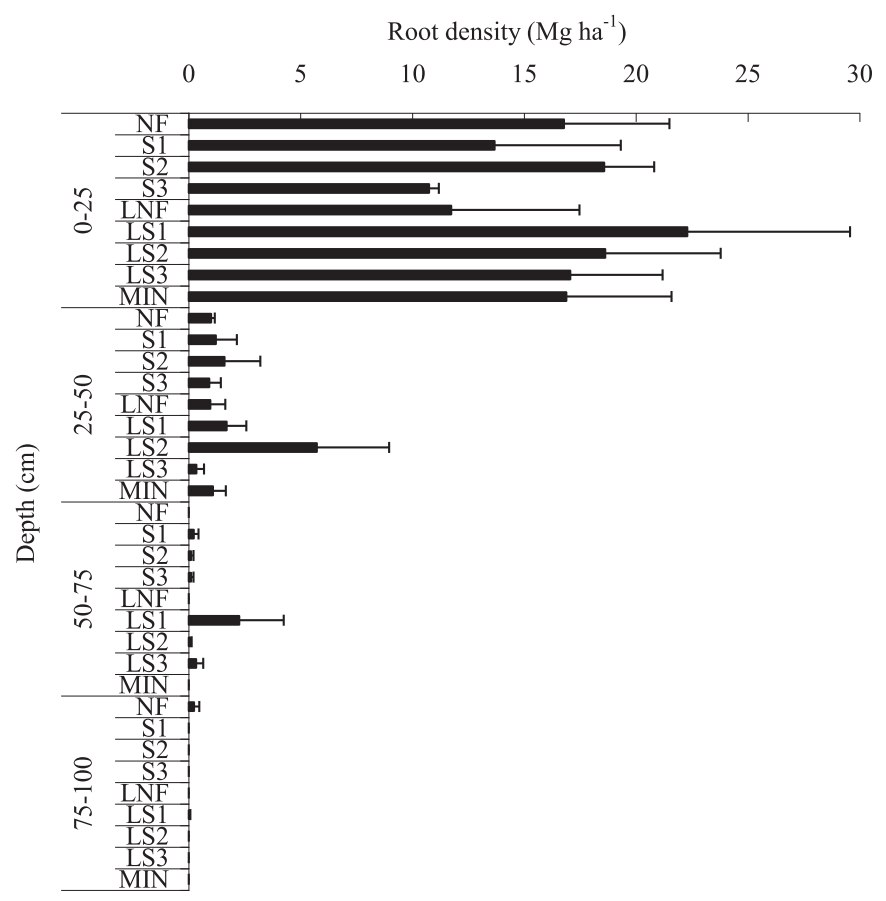

Fig. 6. Root density $\left(\mathrm{Mg} \mathrm{ha}^{-1}\right)$ under each treatment at four soil depths $(0-25,25-50$, 50-75 and 75-100 cm). NF: no fertilizer; S1: low sewage sludge dose (160 kg total N $\mathrm{ha}^{-1}$ ); S2: medium sewage sludge dose ( $320 \mathrm{~kg}$ total $\mathrm{N} \mathrm{ha}^{-1}$ ); S3: high sewage sludge dose (480 $\mathrm{kg}_{\text {total }} \mathrm{N} \mathrm{ha}^{-1}$ ) and MIN: mineral fertilizer. Horizontal lines indicate mean standard error.

negative effect of fast-growing conifer plantations on soil $\mathrm{pH}$ with respect to that of broadleaf trees was also found by Adams et al, (2001) and Rigueiro-Rodríguez et al. (2012a) in grassland afforested with conifers.

Soil bulk density distribution through the soil profile at Pol was generally similar to that observed by other authors such as Tonucci et al. (2011), who examined soil bulk density under silvopastoral systems established in the Brazilian Cerrado (0-10 cm depth: 950, 10-20 cm: 1060, 20-50 cm: 1040 and 50-100: 950; expressed as $\mathrm{kg} \mathrm{m}^{-3}$ ). Soil bulk density in the present study was also significantly lower at depths in which the proportion of sand was higher (upper soil layers) and vice versa, reflecting the fact that sand increases pore volume in the soil and therefore reduces bulk density (Cresswell and Hamilton, 2002). The higher proportion of sand in the upper soil layers could be the result of three possible factors: firstly, the effect of gravity, with fine soil particles, particularly clay, displaced vertically more rapidly than coarse particles (sand) (Oades, 1984); secondly, the absence of livestock in this experiment, without which soil compaction is minimal (Mulholland and Fullen, 1991); and finally, the layer of litterfall derived from the deposition of needles which are initially decomposed into larger aggregates by a set of abiotic and biotic processes. In addition, the development of tree roots could have favoured the downward displacement of finer soil particles (Rield, 1984).

\subsection{Soil depth effect on $C$ sequestration}

The predominance of soil organic $C$ in upper horizons is consistent with worldwide trends and can be explained in part by differences in root distribution which affect the vertical distribution of C in soil (Jobbagy and Jackson, 2000), but also by the vertical C gradient resulting from surficial litter deposition. Several authors, including Dresner et al. (2007) and Mosquera-Losada et al. (2011), have shown that fine roots located in the upper few centimetres of soil are also the main source of organic matter within a soil $\mathrm{C}$ pool. However, it is also important to be aware of the amount of $\mathrm{C}$ stored in deep soil layers, which may reflect input from tree roots (Howlett et al., 2011b). Indeed, the role of deep root systems in the storage of $C$ in deeper soil layers is one of the main premises on which the $C$ sequestration potential of agroforestry is based (Howlett et al., 2011b; Mosquera-Losada et al., 2011; Nair, 2011). Moreover, the final amount of $C$ stored in the upper centimetres of soil in the present study (2010) was lower than that found at the beginning of the experiment (1997). This result may be explained by the reduction in soil $\mathrm{pH}$ which took place during this time, decreasing the incorporation of pine needles into the soil and likely lowering bulk density in the upper soil layers $(0-25 \mathrm{~cm})$ between 1997 and 2010. Robyn and Grogan (2010) observed the same result when comparing agricultural fields with mature forests in Canada.

\subsection{Soil fraction effect on $C$ sequestration}

The vertical distributions of total $C$, percentage of sand and soil bulk density may also explain the $\mathrm{C}$ in the different soil size fractions. In this study, the soil C (expressed as $\mathrm{g} \mathrm{C} \mathrm{kg}^{-1}$ and $\mathrm{MgC} \mathrm{ha} \mathrm{CH}^{-1}$ ) associated with macroaggregates $(250-2000 \mu \mathrm{m})$ in the upper centimetres of soil was higher than that stored in both microaggregates $(53-250 \mu \mathrm{m})$ and smaller aggregate sizes $(<53 \mu \mathrm{m})$, a pattern also observed by Tisdall and Oades (1982) and Howlett et al. (2011a). Increased C storage in macroaggregates is generally caused by a high proportion of sand in upper soil layers, greater $C$ input and the preferential stabilization of organic matter in macroaggregates as opposed to smaller size classes. However, the amount of $C$ stored in smaller aggregates $(<53 \mu \mathrm{m})$ in deeper soil layers was greater than that found in macro and microaggregates, as also observed by Jimenez et al. (2008) in forest stands in northeastern Costa Rica. This result is very important, since previous studies have shown macroaggregates to contain active $C$ which is very susceptible to release after changes in land use and soil management (i.e. ploughing, fertilization), as well as being sensitive to changes in organic matter dynamics associated with meteorological variation (Saha et al., 2009). In contrast, smaller aggregates are more stable than macroaggregates in soil, and being linked with recalcitrant plant/microbial residue and clay minerals they are therefore associated with $C$ that is relatively old (Blanco-Canqui and Lal, 2004), which is important with respect to long-term $C$ sequestration. Moreover, the mean residence time of $C$ associated with smaller soil fractions $(<53 \mu \mathrm{m})$ and stored in deep soil layers will also likely be high, since this $C$ is recalcitrant and may be a product of the thermal degradation of organic material (such as roots) in the absence of air (pyrolysis) (Lehmann et al., 2011). Recalcitrant C may also be strongly adsorbed by Al oxides (Kaiser and Zech, 2000), which are abundant in the exchange complexes of very acid soils such as those found in the present study (López-Díaz et al., 2007). This would then retard the mineralization of organic C (Miltner and Zech, 1997) and favour long-term $C$ sequestration in deeper rather than shallower soil layers. These results are consistent with those found by Glaser et al. (2003) regarding Amazonian dark earths.

\subsection{Effect of liming and sewage sludge application on the variables analysed}

In terms of the effect of treatment type on soil chemical and physical properties, soil pH was modified only in the upper centimetres, probably as a result of the development of pasture and trees in previous years. Accordingly, in those treatments in which tree growth and pasture production was higher (MIN and S2) (LópezDíaz et al., 2007), a reduction in soil pH was observed due to the increase in the extraction of soil cations. Similar findings were 
observed by Rigueiro-Rodríguez et al. (2012b) in afforested and agronomic soils in northwest Spain which were also fertilized with sewage sludge ( $320 \mathrm{~kg}$ total $\mathrm{N} \mathrm{ha}^{-1}$ ). However, soil bulk density at 0-25 cm depth did not vary with soil management, due to the previously-described factors affecting this variable (i.e. organic matter deposition, gravity, root development ...) being similar between treatments at this shallow depth. In contrast, treatment type did have an effect on soil C associated with large $(250-2000 \mu \mathrm{m})$ and small aggregates $(<53 \mu \mathrm{m})$ in the upper centimetres of soil. The application of a large dose of sewage sludge and lime reduced the amount of $C$ stored in the $250-2000 \mu \mathrm{m}$ soil fraction (when expressed as either $\mathrm{g} \mathrm{C} \mathrm{kg}^{-1}$ or $\mathrm{MgC} \mathrm{ha}{ }^{-1}$ ) to a greater extent than other limed sewage sludge doses. Liming and a large dose of sludge also led to a decrease in the amount of $\mathrm{C}$ associated with the $<53 \mu \mathrm{m}$ soil fraction $\left(\mathrm{Mg} \mathrm{C} \mathrm{ha}^{-1}\right)$ in comparison with the NF treatment. These results may reflect the fact that the input of $\mathrm{N}$ to the soil via fertilization with large amounts of sewage sludge probably reduced the $\mathrm{C} / \mathrm{N}$ ratio, increasing the mineralization of existing SOM (Youkhana and Idol, 2009) mainly when in combination with liming.

The most significant effect of treatment variation was observed at depths of $25-50 \mathrm{~cm}$ and $50-75 \mathrm{~cm}$, in soil which is probably less affected by litter input and understory root development than upper layers. At $25-50 \mathrm{~cm}$ depth, levels of sand were higher not only in treatments involving lower soil input of sludge and therefore organic matter (S1 compared with S2 and LS3), but also in the MIN treatment. The latter was likely characterized by increased input of inorganic $\mathrm{N}$ to the soil with respect to the S2 and LS3 treatments, with clay levels higher in the S2 than the S3 treatment leading to inadequate sludge incorporation (López-Díaz et al., 2007). The low input of N (in S1) probably limited the incorporation of SOM and therefore increased the amount of coarse particles in the soil, while the MIN treatment likely increased the mineralization of existing SOM (Youkhana and Idol, 2009). The acceleration of SOM mineralization caused by the MIN treatment probably also resulted in a reduction in bulk soil total $C$ and the amount of $C$ stored in the 250-2000 $\mu \mathrm{m}$ soil fraction compared to those treatments in which sewage sludge was applied. At $25-50 \mathrm{~cm}$ depth, as was observed in the layer above, a high dose of sewage sludge combined with lime was associated with a reduction in the amount of $C$ associated with the $<53 \mu \mathrm{m}$ soil fraction when compared with the NF treatment.

At $50-75 \mathrm{~cm}$ depth, the combination of lime and a medium dose of sewage sludge increased the percentage of sand in the soil and reduced the amount of clay compared with the application of a high dose of sludge with lime. This result was also observed at 75-100 cm, and may be explained by the greater tree root development observed in the less fertilized plots (López-Díaz et al., 2007). In the deeper soil layer, a negative effect of liming on $C$ associated with the $<53 \mu \mathrm{m}$ soil fraction was seen in the NF treatment, which may reflect the input of Ca to the soil from lime which usually accelerates SOM mineralization in very acid soils (Wheeler, 1998). At $75-100 \mathrm{~cm}$ depth, it was also found that a combination of the NF treatment and liming generally reduced the amount of $\mathrm{C}$ stored in the $250-2000 \mu \mathrm{m}$ soil fraction to a greater extent than did the application of a medium dose of sewage sludge with lime, probably due to the latter's high organic matter content (MosqueraLosada et al., 2010). The liming effect could reflect earlier Ca input which increased SOM mineralization in these deeper soil layers after leaching.

Finally, it is important to be aware that in the uppermost metre of soil, both low and medium doses of sewage sludge were associated with a relative increase in total $C$ and $C$ stored in the $250-2000 \mu \mathrm{m}$ soil fraction with respect to a high dose. However, the NF treatments did not reduce levels of $C$ in the $<53 \mu \mathrm{m}$ soil fraction. This treatment therefore positively affected soil C sequestration since the $C$ associated with smaller aggregates sizes $(<53 \mu \mathrm{m})$ is stored in the soil for a longer period of time (BlancoCanqui and Lal, 2004; Lehmann et al., 2011).

\section{Conclusion}

Seventeen years after reforestation and seven years after tree canopy closure, strong gradients were formed as a result of litter deposition and nutrient leaching. Soil bulk density and $\mathrm{pH}$ were lower in upper than in deeper soil layers due to litter deposition, and cation extraction and leaching, respectively. The reverse pattern was observed regarding coarse soil particles and total and soil fraction $C$ storage. SOC was negatively affected by a combination of liming and a high dose of sewage sludge, as this treatment activated SOM mineralization in both coarse aggregates in upper layers (compared to the effect of lower sewage sludge doses) and in microaggregates (compared with NF). The negative effect of liming on $C$ associated with microaggregates was apparent in the deepest soil layer as a result of Ca leaching when no sludge was applied. Even though the input of lime or sewage sludge generally negatively affected soil $C$ storage, such a reduction could potentially be compensated by increased vegetation development, as found in plots subject to intermediate sludge doses.

\section{Acknowledgements}

We are grateful to FEDER, CICYT, XUNTA (Consolidation funds) and European Commission (AGFORWARD), ( $\mathrm{N}^{\circ}$ 613520) for financial assistance and to Escuela Politécnica Superior for the use of their facilities. We also acknowledge José Javier Santiago-Freijanes, Divina Vázquez-Varela, Pablo Fernández Paradela and Teresa Piñeiro-López for their help with sample processing both in the laboratory and in the field. This research was funded, in part, by the Educational, Science and Technology Ministry (CICYT) and the autonomous regional government of Xunta de Galicia.

\section{Appendix A. Supplementary data}

Supplementary data related to this article can be found at http:// dx.doi.org/10.1016/j.jenvman.2014.10.015.

\section{References}

Adams, M.L., Davis, M.R., Powell, K.J., 2001. Effects of grassland afforestation on exchangeable soil and soil solution aluminium. Aust. J. Soil Res. 39, 1003-1004.

Blanco-Canqui, H., Lal, R., 2004. Mechanisms of carbon sequestration in soil aggregates. Crit. Rev. Plant Sci. 23, 481-504.

BOE (Spanish Official Bulletin), 1990. Real Decreto 1310/1990 29 de Octubre de 1990, que regula la utilización de los lodos de depuración (Royal Decree 1310/ 1990 29th October 1990, that regulates the use of sewage sludge). Ministerio Agricultura, Pesca y Alimentación, Madrid, Spain. http://www.boe.es/boe/dias/ 1990/11/01/pdfs/A32339-32340.pdf (accessed 11.01.12.).

Cresswell, H.P., Hamilton, G.J., 2002. Bulk density and pore space relations. In: McKenzie, N., Coughlan, K., Cresswell, H. (Eds.), Soil Physical Measurement and Interpretation for Land Evaluation. CSIRO, Australia, pp. 3-58.

Dixon, R.K., 1995. Agroforestry systems: sources or sinks of greenhouse gases? Agroforest. Syst. 31, 99-116.

Dresner, S., Ekins, P., McGeevor, K., Tomei, J., 2007. Forest and climate change global understandings and possible responses. In: Freer-Smith, P.H., Boradmeadow, M.S.J., Lynch, J.M. (Eds.), Forestry and Climate Change. CAB International, Wallingford, UK, pp. 38-48.

Elliott, E.T., 1986. Aggregate structure and carbon, nitrogen, and phosphorus in native and cultivated soils. Soil Sci. Soc. Am. J. 50, 627-633.

EPA (Environmental Protection Agency), 1994. Land Application of Sewage Sludge. A Guide for Land Appliers on the Requirements of the Federal Standards for the Use of Disposal of Sewage Sludge, 40 CFR Part 503. Environment Protection Agency, Washington, USA.

EU (European Union), 1986. DOCE n ${ }^{\circ}$ L 181 04/07/1986.Council Directive 86/278/EEC of 12 June 1986 on the Protection of the Environment and, in Particular of the Soil, 
when Sewage Sludge is Used in Agriculture. http://eurlex.europa.eu/LexUriServ/ LexUriServ.do?uri=CELEX:31986L0278:ES. HTML (accessed 11.01.12.).

EU (European Union), 2005. Council Regulation (EC) $n^{\circ} 1698 / 2005$ of Septembre 2005 on Support for Rural Development by the European Agricultural Fund for Rural Development. http://eurlex.europa.eu/LexUriServ/LexUriServ.do?uri=OJ. L:2005:277:0001:0040:EN: PDF (accessed 15.03.12.).

Faithfull, N.T., 2002. Methods in Agricultural Chemical Analysis. CABI Publishing, Wallingford, UK.

Fernández-Núñez, E., Rigueiro-Rodríguez, A., Mosquera-Losada, M.R., 2010. Carbon allocation dynamics one decade after afforestation with Pinus radiata D. Don and Betula alba L. under two stand densities in NW Spain. Ecol. Eng. 36, 876-890.

Fisher, M.J., Rao, I.M., Ayarza, M.A., Lascano, C.E., Sanz, J.I., Thomas, R.J., Vera, R.R. 1994. Carbon storage by introduced deep-rooted grasses in the South American savannas. Nature 371, 236-238.

Guitián-Ojea, F., Carballás-Fernández, T., 1976. Técnicas de Análisis de Suelos. Editorial Pico Sacro, Santiago de Compostela, Spain.

Glaser, B., Guggenberger, G., Zech, W., Ruivo, M.L., 2003. Soil organic matter stability in Amazonian dark earths. In: Lehmann, J., Kern, D.C., Glaser, B., Woods, W.I. (Eds.), Amazonian Dark Earths: Origin, Properties, Management. Kluwer Academic Publishers, Netherlands, pp. 141-158.

Howlett, D.S., Moreno, G., Mosquera-Losada, M.R., Nair, P.K.R., Nair, V.D., 2011a. Soil carbon storage as influenced by tree cover in the Dehesa cork oak silvopasture of central-western Spain. J. Environ. Monit. 13, 1897-1904.

Howlett, D.S., Mosquera-Losada, M.R., Nair, P.K.R., Nair, V.D., Rigueiro-Rodríguez, A., 2011b. Soil carbon storage in silvopastoral systems and a treeless pasture in Northwestern Spain. J. Environ. Qual. 40, 825-832.

Jiménez, J.J., Lal, R., Russo, R.O., Leblanc, H.A., 2008. The soil organic carbon in particle-size separates under different regrowth forest stands of north eastern Costa Rica. Ecol. Eng. 34, 300-310.

Jobbágy, G.E., Jackson, R.B., 2000. The vertical distribution of soil organic carbon and its relation to climate vegetation. Ecol. Appl. 10, 423-436.

Kaiser, K., Zech, W., 2000. Sorption of dissolved organic nitrogen by acid subsoil horizons and individual mineral phases. Eur. J. Soil Sci. 51, 403-411.

Kowalenko, C.G., 2001. Assessment of Leco CNS-2000 analyzer for simultaneously measuring total carbon, nitrogen and sulphur in soil. Commun. Soil Sci. Plant Anal. 32, 2065-2078.

Lavelle, P., Spain, A., 2001. Soil Ecology. Kluwer Academic Publishers, Dordrecht.

Lehmann, J., Rillig, M.C., Thies, J., Masiello, C.A., Hockaday, W.C., Crowley, D., 2011. Biochar effects on soil biota - a review. Soil Biol. Biochem. 43, $1812-1836$.

López-Díaz, M.L., Mosquera-Losada, M.R., Rigueiro-Rodríguez, A., 2007. Lime, sewage sludge and mineral fertilization in a silvopastoral system develop in very acid soils. Agroforest. Syst. 70, 91-101.

Miltner, A., Zech, W., 1997. Effects of mineral on the transformation of organic matter during simulated fire-induced pyrolisis. Org. Geochem. 26, 175-182.

Moreno, G., Obrador, J.J., Cubera, E., Dupraz, C., 2005. Fine root distribution in dehesas of central-western Spain. Plant Soil 277, 153-162.

Mosquera-Losada, M.R., Muñoz-Ferreiro, N., Rigueiro-Rodríguez, A., 2010. Agronomic characterisation of different types of sewage sludge: policy implications. Waste Manag. 30, 492-503.

Mosquera-Losada, M.R., Freese, D., Rigueiro-Rodríguez, A., 2011. Carbon sequestration in European agroforestry systems. In: Mohan Kumar, B., Nair, P.K.R. (Eds.), Carbon Sequestration Potential of Agroforestry Systems Opportunities and Challenges. Springer, Dordrecht, The Netherlands, pp. 43-59.

Mulholland, B., Fullen, M.A., 1991. Cattle trampling and soil compaction on loamy sands. Soil Use Manag. 7, 189-193.

Nair, P.K.R., Nair, V.D., Kumar, B.M., Showalter, J.M., 2010. Carbon sequestration in agroforestry systems. Adv. Agron. 108, 237-307.

Nair, P.K.R., 2011. Agroforestry systems and environmental quality: introduction. J. Environ. Qual. 40, 784-790.
Nair, P.K.R., 2012. Climate change mitigation and adaptation: a low-hanging fruit of agroforestry. In: Nair, P.K.R., Garrity, D. (Eds.), Agroforestry-the Future of Global Land Use. Advances in Agroforestry 9. Springer, Dordrecht, The Netherlands, pp. $31-67$.

Nillsson, S.I., 2004. Soil acidification. In: Benbi, D.K., Nieder, R. (Eds.), Handbook of Processes and Modelling in the Soil-plant System. Haworth Press, London, pp. 177-199.

Oades, J.M., 1984. Soil organic matter and structural stability: mechanisms and implications for management. Plant soil 76, 319-337.

Palma, J.H.N., Graves, A.R., Burgess, P.J., Deesman, K.J., van Keulen, H., Mayus, M., Reinser, Y., Herzog, F., 2006. Methodological approach for the assessment of environmental effects of agroforestry at the landscape scale. Ecol. Eng. 29, $450-462$.

Paul, K.I., Polglase, P.J., Nyakuengama, J.G., Khanna, P.K., 2002. Change in soil carbon following afforestation. Forest Ecol. Manag. 168, 241-257.

Reijneveld, J.A., Kuikman, P.J., Oenema, O., 2010. Changes in soil organic matter content of grassland and maize land in the Netherlands between 1970 and 2009. Grassl. Sci. Eur. 15, 3-32.

Rield, O., 1984. The role of forests in water economy and soil protection. In: Riedl, O., Zachar, D. (Eds.), Developments in Agricultural and Managed-forest Ecology. Forest Amelioration. Elsevier, Amsterdam, pp. 234-247.

Rigueiro-Rodríguez, A., Mosquera-Losada, M.R., Fernández-Núñez, E., 2012a. Afforestation of agricultural land with Pinus radiata D. Don and Betula alba LNW Spain: Effects on Soil pH, Understorey Production and Floristic Diversity Eleven Years after Establishment. Land Degrad. Dev. 23, 227-241.

Rigueiro-Rodríguez, A., Mosquera-Losada, M.R., Ferreiro-Domínguez, N., 2012b. Pasture and soil zinc evolution in forest and agriculture soils of Northwest Spain three years after fertilisation with sewage sludge. Agric. Ecosyst. Environ. 150, 111-120.

Robyn, L.F., Grogan, P., 2010. Soil carbon accumulation during temperate forest succession on abandoned low productivity agricultural lands. Ecosystems 13, 795-812.

Rodríguez-Murillo, J.C., 2001. Organic carbon content under different types of land use and soil in peninsular Spain. Biol. Fert. Soils 33, 53-61.

Saha, S., Nair, P.K.R., Nair, V.D., Kumar, B.M., 2009. Soil carbon stock in relation to plant diversity of homegardens in Kerala, India. Agroforest. Syst. 76, 53-65.

SAS, 2001. SAS/Stat User's Guide: Statistics. SAS Institute Inc, Cary, NC, USA.

Sauer, T.J., Cambardella, C.A., Brandle, J.R., 2007. Soil carbon and tree litter dynamics in a red cedar-scotch pine shelterbelt. Agroforest. Syst. 71, 163-174.

Six, J., Callewaert, P., Lenders, S., De Gryze, S., Morris, S.J., Gregorich, E.G., Paul, E.A., Paustian, K., 2002a. Measuring and understanding carbon storage in aff orested soils by physical fractionation. Soil Sci. Soc. Am. J. 66, 1981-1987.

Six, J., Conant, R.T., Paul, E.A., Paustian, K., 2002b. Stabilization mechanisms of soil organic matter: implications for C-saturation of soils. Plant Soil 241, 155-176.

Tisdall, J.M., Oades, J.M., 1982. Organic matter and water stable aggregates in soils, J. Soil Sci. 33, 141-163.

Tonucci, R.G., Nair, P.K.R., Nair, V.D., Garcia, R., Bernardino, F.S., 2011. Soil carbon storage in silvopasture and related land-use systems in the Brazilian Cerrado. J. Environ. Qual. 40, 833-841.

USDA (U.S. Department of Agriculature), 2006. Keys to Soil Taxonomy, 10th ed USDA Natural Resources Conservation, Washington, USA.

Wheeler, D.M., 1998. Investigation into mechanisms causing lime responses in a grass/clover pasture on a clay loam soil. New Zeal. J. Agr. Res. 41, 497-515.

Whitehead, D.C., 1995. Grassland Nitrogen. CAB International, Wallingford, UK.

Youkhana, A., Idol, T., 2009. Tree pruning mulch increases soil $\mathrm{C}$ and $\mathrm{N}$ in a shaded coffee agroecosystem in Hawaii. Soil Biol. Biochem. 41, 2527-2534.

Zas, R., Alonso, M., 2002. Understory vegetation as indicators of soil characteristics in northwest Spain. For. Ecol. Manag. 171, 101-111.

Zhang, Y., Zhao, Y.C., Shi, X.Z., Lu, X.X., Yu, D.S., Wang, H.J., Sun, W.X., Darilek, J.L., 2008. Variation of soil organic carbon estimates in mountain regions: a case study from Southwest China. Geoderma 146, 449-456. 